\title{
The Forest Resources Information System to Support Sustainable Forest Management: Case Study Perum Perhutani
}

\author{
Ahsana Riska $^{1 *}$, Muhamad Buce Saleh ${ }^{2}$, Hendrayanto $^{2}$ \\ ${ }^{1}$ Graduate School of Bogor Agricultural University, Dramaga Main Road, Campus IPB Dramaga, Bogor, Indonesia 16680 \\ ${ }^{2}$ Department of Forest Management, Faculty of Forestry, Bogor Agricultural University, Academic Ring Road, Campus IPB \\ Dramaga, Bogor, Indonesia 16680
}

Received July 22, 2016/Accepted December 24, 2016

\begin{abstract}
Forest resources information system aims to provide accurate and complete information periodically to support effective and efficient decision-making process. Perum Perhutani is the oldest state-owned enterprise for forestry in Indonesia. They have been developed sustainable forest management include the information system. Although forest resources information system already exists, forest quality decreases time by time. This research study aims to improve the effectiveness of forest resources information system in Perum Perhutani related to forest resources management. This study focused the observation on mechanism and supporting variables of forest resources information system and influence of forest resources information system on the decision-making process. Mechanism and supporting variables of forest resources information system show how is forest resources information system been working to support the decision-making process. The research was conducted by reviewing literature and depth interviewing with key informants. The results showed that the current forest resources information system could not support sustainable forest management in Perum Perhutani. This information system has weakness in data and information, procedures, technology, and user. Decision-making process highly adopts technocratic paradigm, centralized, and technically dominated by decision-maker preferences which give direct affect on information management at the site level. Forest management unit as a manager at the site level become information provider but have no authority to use information to decide management
\end{abstract}

Keywords: forest resources information system, SISDH, decision making, Perum Perhutani

*Correspondence author, email: ahsanariska@gmail.com,ph.: +62-8111148988

\section{Introduction}

Data and information are essential factors in the decisionmaking process. Data presents facts, while information is the result of data analysis that arranged based on its objectives (Pearlson \& Saunders 2010). Information systems as data and information management evolve as the development of technology. Organizations use information in all aspects such as planning, controlling, arrangement, and decisionmaking. Therefore, information becomes an important resource for organization (Walsham 2009). Information systems defined by Buckingham et al. (1987) as a system that collects, stores, processes, and displays information associated with the organization. The importance of information system extends to planning, processing, storage, and dissemination of information and data to carry out the function of management (Arias \& Solana 2013). Information system supports the decision makers by providing information and alternative options. The decision makers then decide based on the existing alternatives or by preferences and shared values of the decision makers.

The forest resources information system has been known for years due to its importance for forest resources management. For the last 2 decades, many new methods performed to mensuration of forest and forest management information processing, optimization of forest designing and forestry planning, and the creation of forest resources information system (Atrishchencko 2013). Forest resources information system aims to provide accurate and complete information periodically to support an effective and efficient decision-making process. Forest management needs various information which integrated from various aspects of the organization. This becomes a challenge to develop the better performance of information systems. Kuru (2000) explained that integrated information system in forest management can improve data efficiency, reduce data redundantly, and optimize the using of information. Integrated information system has characteristics such:

1 Effective data management procedure, data storage, data processing and data delivery to user.

2 Coherent, efficient, and transparent data structures that closely match the requirements of the organization and data management procedures.

3 Generic data structures using common naming conventions and field formats. 
Perum Perhutani is the oldest state-owned enterprises in Indonesia which responsible for managing state forest especially in Java. They managed the natural forest for protection function and plantation forest for wood production especially teak that has been planted since the era of Dutch colonialism. Perum Perhutani since a long time has been practicing sustainable forest management for plantation forest, including forest resource information system (SISDH) to support sustainable forest management (Perum Perhutani 2000; 2015).

Perum Perhutani has been practicing management of SISDH to determine their potential and process the information into forest management policies. According to the study of Fakultas Kehutanan UGM (2014), Perum Perhutani information system (SISDH) has weakness in the monitoring system of forest resources and technical management of database management. These both aspects influence the performance of forest resources information system to fulfill its aim to support the decision-making process. In other words, Perum Perhutani information system still unable to support forest management to be better. Data and information of the plantation forest have been shown unsustained forest characteristics, such as abnormal forest classes. The structure of forest class shows that forest classes dominated by young age class and widespread of the vacant land. Vacant land is non-forested land as an impact of inability to maintain the plantation and the standing stocks. These conditions lead to decreasing performance of sustainable production which is directly correlated to the financial sustainability of the organization (Perum Perhutani 2010).

An information system is an optimum if used in the process of decision making. Which is mean information systems can fulfill its objectives to support decision-making process (Rondeaux 1991; De Lone \& Mc Lean 2003; Platisa $\&$ Balaban 2009). This research study aims to improve the effectiveness of SISDH in Perum Perhutani related to forest resources management. This study focused the observation on:

1 Mechanism and supporting variables of forest resources information system.

2 Influence of forest resources information system on the decision-making process. Mechanism and supporting variables of forest resources information system show how is forest resources information system been working to support the decision-making process.

\section{Methods}

Case study We observed the operation of forest resources information system in 3 levels of management, which are forest management unit $(\mathrm{KPH})$ as management unit on the site represented by $\mathrm{KPH}$ Bogor, regional division represented by Forest Planning Section (SPH) Bogor, and Board of Directors as a central management level. This study examined how SISDH works in forest planning and forest management activities in each level of managements. Data collection and analysis was done from November 2015-June 2016.

\section{Data collection}

\section{Document collection}

The collected documents are related to SISDH such as standard operating procedures to draft planning documents (work procedures), planning documents, and literature that support the data analysis. These documents are listed in Table 1.

2 Interview

An in-depth interview with determined key informants was used in this study. Interviews were conducted unstructured and depth to enable the acquisition of more complex and depth data (Denzin \& Lincoln 2009). Digging information from the key informants means, speakers have been determined in advance (Bungin 2003). The criteria from key informants include:

1 The subject has been work related to the certain activities or field of activity for some period. In this case, the activities or field of activity related to forest management in Perum Perhutani especially for forest resources information system aspect.

2 The subject still fully involved/active in the environment or the activities that concern the research.

3 The subject that has time and opportunity to be interviewed.

From the criteria of key informants, we interviewed 5 key informants.

Data analysis Data analysis used triangulation method. Creswell (2012) stated that in qualitative research, validation with triangulation method done by collecting data from various sources both literature and interviews. Furthermore, data observed and all documents analyzed entirely. Bungin (2003) also argued that the technical triangulation is prioritizing the effectiveness of the process and desired outcomes. This study used triangulation of sources method. This method examining the consistency of data and information from the different source, in this case from various interviewees and various documents which are the inputs of this study.

Observation of the Perum Perhutani information system (SISDH) based on information system components which proposed by Turban et al. (2007) and Cheung et al. (2014). Components assessed at the level of planning and management of forest resources related to:

1 Data

The word data refers to a collection of facts or figures when data transformed through processes analysis to a form that meaningful to a user, it is referred to as information. We observed the type of collected data and resulted in information. The transformation of data into useful information is the core function of information systems.

2 Procedure

We observed collecting data procedure, updating data procedure and sharing/coordination data procedure. Collecting data procedures refers to collected of any and all data that maybe deemed pertinent to an organization's 
Table 1 List of collected procedures and planning documents from Perum Perhutani

\begin{tabular}{|c|c|c|}
\hline Title & Year & Description \\
\hline $\begin{array}{l}\text { Standard operation procedure for Forest Resources } \\
\text { Information System and Geospatial Information } \\
\text { System with Electronically Management Data }\end{array}$ & 2000 & $\begin{array}{l}\text { Describe as a guidance to operate forest resources information } \\
\text { system for potential forest databases and spatial databases. }\end{array}$ \\
\hline $\begin{array}{l}\text { Work Procedure for Sustainability of Forest } \\
\text { Management Plan }\end{array}$ & 2013 & $\begin{array}{l}\text { Describe as a guidance to drafting Sustainability for Forest } \\
\text { Management Plan (RPKH) for one cultivation period. }\end{array}$ \\
\hline Work Procedure for Annual Technical Plan & 2013 & $\begin{array}{l}\text { Describe as a guidance to drafting Annual Technical Plan. Its } \\
\text { consist of Annual Technical Nursery Plan, Annual Technical } \\
\text { Planting Plan, Annual Technical Production Plan, Annual } \\
\text { Technical Non Timber Harvesting Plan, Forest Inf rastructure } \\
\text { Annual Plan, Annual Social Management Plan, and Annual } \\
\text { Environment Management Plan. }\end{array}$ \\
\hline Work Procedure for Work Plan and Budget & 2014 & $\begin{array}{l}\text { Describe as a guidance to support company activities in finance } \\
\text { field. }\end{array}$ \\
\hline Work Procedure for Long Term Plan & 2014 & $\begin{array}{l}\text { Describe as a guidance to drafting company's plan in } 5 \text { years } \\
\text { period. }\end{array}$ \\
\hline $\begin{array}{l}\text { Sustainability of Forest Management Plan (RPKH) of } \\
\text { Bogor Forest Unit Management }\end{array}$ & 2015 & Forest management plan for one period of one cultivation class. \\
\hline $\begin{array}{l}\text { Obor Book of RPH Cigudeg, BKPH Jasinga- } \\
\text { Leuwiliang, KPH Bogor }\end{array}$ & 2015 & $\begin{array}{l}\text { Manual database book of forest sources condition in the area. This } \\
\text { book compiled by Head of Resort Forest Management, a lowest } \\
\text { level management unit in KPH. }\end{array}$ \\
\hline Job description of Forest Planning Section & - & $\begin{array}{l}\text { Describe job descr iption for stuctural member of Forest Planning } \\
\text { Section. }\end{array}$ \\
\hline Job description of Head of KPH & - & Describe job description for Head of KPH. \\
\hline
\end{tabular}

operation. Updating data procedure refers to mechanisms and time data updates. While sharing/coordination data procedure refers to mechanisms to integrate all needed data and information from various parts of the organization to form an information that can be retrieved as needed by management organization.

3 User

We observed user of SISDH at Perum Perhutani and analyze the use of information in the decision-making process on forest resources management. The user observed vary from the lowest level management unit on the site to the central management.

4 Technology

We observed technology that is used in SISDH and its usability for the user. The main observation is hardware, software, and how the user satisfaction of current technology in the SISDH in Perum Perhutani.

DeLone and McLean (2003) and Athanasiadis and Areopoulou (2013) suggested that an information system should pay attention to the quality of information, quality of the system, and quality of service. These criteria's were used to assess the quality of forest resources information systems at Perum Perhutani. The flowchart to assist the criteria as shown in Figure 1. The decision process is influenced by the information, sharing value, and the decision makers preferences (Marchand \& Kettinger 2011; Harris 2012). Analysis of the decision-making process examines what dominant variable used by decision makers related to forest management in Perum Perhutani.

\section{Result and Discussion}

Variables and mechanism of forest resource information systems in planning and management of forest resources at Perum Perhutani Planning system in Perum Perhutani is divided into 2 subsystems. Enterprise planning is managed by management planning unit and forest resources planning is managed by forest planning unit (Fakultas Kehutanan

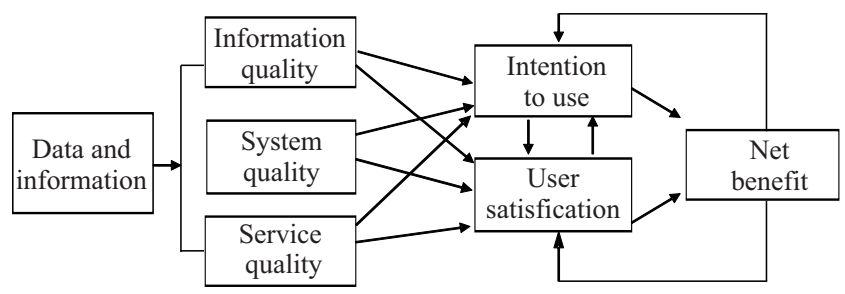

Figure 1 Data analysis flowchart.

UGM 2014). Enterprise planning system is used to control the financial benefits refers to the policy of Ministry of Stateowned Enterprises. While the forest resource planning system is used to control the preservation of forest (standing stock) refers to the Forest Plan both at national and provincial levels. Both of planning systems are isolated and not mutually subordinated with each other. Typically as an organization, Perum Perhutani has planning hierarchy ranging from long-term planning to operational planning. Figure 2 shows planning hierarchy of Perum Perhutani. Planning hierarchy describes management plans in both of subsystems planning.

SISDH was observed within the context of forest planning and management. Information system products in form of databases and information are used for forest resources planning. A management plan for forest sustainability (RPKH) is a basis of the long-term plan of the company (RJP) which is elaborated into annual work plan budget (RKAP). Whereas in the forest resources management context, RPKH elaborate into the annual technical plan (RTT) for operational management.

SISDH in Perum Perhutani is understood as an instrument to formulate RPKH. The variable of the forest resources information system at Perum Perhutani according to Turban et al. (2007) and Cheung et al. (2014) described in 


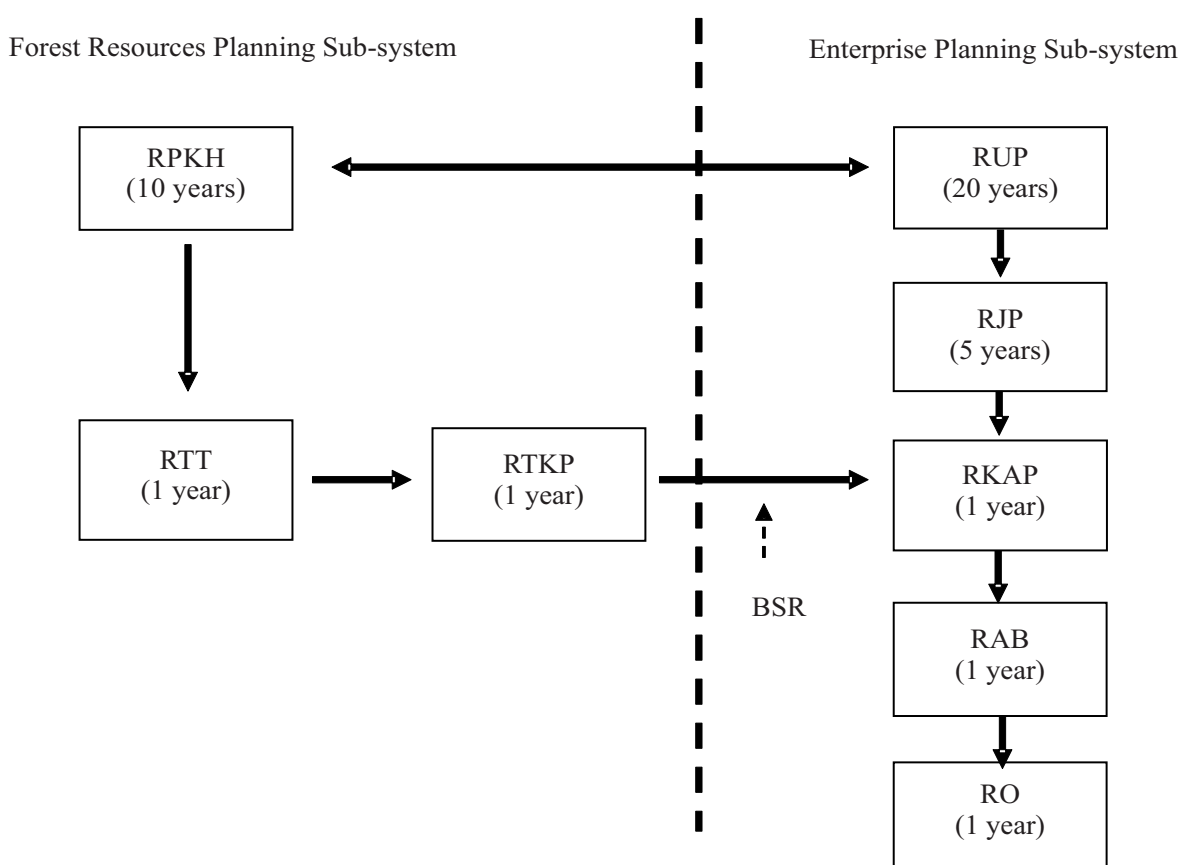

Note: RPKH : Rencana Pengaturan Kelestarian Hutan (Forest Sustainability Management Plan), RTT : Rencana Teknik Tahunan (Annual Technical Plan), RKTP : Rencana Kerja Teknis Perusahaan (Technical Work Plan of the Company), BSR : Biaya Standar Rata-rata (Standard Cost Average), RUP : Rencana Umum Perusahaan (General Plan of the Company), RJP : Rencana Jangka Panjang (Long Term Plan of the Company), RKAP : Rencana Kerja Anggaran Perusahaan (Budget Work Plan of the Company), RAB : Rencana Anggaran Biaya (Budget Plan), RO : Rencana Operasional (Operational Plan)

Figure 2 Planning system in Perum Perhutani.

the following points:

1 Data

We found 2 types of databases that were used in the SISDH, SISDH-PDE, and SIG-PDE. SISDH-PDE stands for sistem informasi sumber daya hutanpengolahan data elektronik. It consists of databases of forest resources, forest management database, companyowned area database, agrarian database, forest security database, and social database. SIG-PDE stands for sistem informasi geografis-pengolahan data elektronik. It was prepared to organize spatial data. This is for facilitating the provision of data in a map-making process that is usually required to be an annex in the RPKH book. The geography information system (GIS) function should not only as a storage database though in the early of its development its purposes to resources inventories, cadastral, planning, transportation, and census. More than that by this time GIS has been widely used for modeling and decision making (Prasetyo 2013).

In the planning context, databases of forest resources are used to compile forest management planning. From the interview at the KPH, SPH, and Board of Directors level, there was a consistent statement that information system in Perum Perhutani was only focused on the availability of physical data of forest resources. Other supporting data such social and environment data become the complementary in the forest resources management plan. This lack of data due to the difference of division authority. Management plan of forest resources is domain authority of forest resources planning unit, while social management is domain authority of another division. Between that division, there is no integration mechanism to support forest resources management plan.

In the context of management, the database is used to support the decision-making process. Management decisions are based on the management plan that has been made. If there is a difference, the proponent has to make a prior study. This study requires supporting data such as social data, economic and environmental data.

Data of forest resources in SISDH-PDE and spatial data in SIG-PDE are potentially not connected. This is because databases of forest resource are managed in the $\mathrm{KPH}$ or SPH level while the spatial data are managed in the Regional Division. Thus, updating data mechanism has to follow bureaucratic processes that require more time and cost.

2 Procedure

Procedures that observed in this study were data collection and databases preparation procedure, data processing procedures, and updating data procedures.

2.1 Data collection and databases preparation procedure

The forest resources data collection was processed in KPH and SPH level. The collected data by data publisher was recapitulated per subplot. It was consist of planting activities, maintenance, timber and nontimber harvesting, and also forest class changing due to disturbance of forest security or natural disaster which needs 
amandement statement (BAP). Another data such as company's land was compiled from notes and proof of ownership and the use of company's land. Meanwhile, the agrarian databases were compiled from notes of agrarian problem which occur in each subplot. This recapitulated data then input into the computerized database system of forest resources.

The preparation of SIG-PDE databases was begun with terrestrial measurement conducted by surveyors from measurements and mapping subsection. The master map digitized to input into computerized GIS system. This result then connected to the forest resources data. The final output of this process was a digital master map with a scale of 1:10.000 and maps for RPKH's annex.

2.2 Processing data procedure

Databases processing in the forest resources planning context was done to compile the forest resources management plans. The main output is RPKH. Then, elaborated into RTT for each forest management activities which become a basis to compile RKAP. In the forest resources management context, data processing was used to produce supporting information for forest resources decision-making.

Refers to the sources, data and information that were used in the forest information systems focused only on forest resources data. Social and environmental data become complementary, not a considered variables for forest resources management plans. It was implicated to the increasing of crop failure phenomenon and number of vacant land because of pre-condition of the land was not prepared in advanced.

2.3 Updating data procedures

Forest resources updating data processes were done periodically in several activities. Including, interstice forest inventory or RPKH revision once in every 5 years for 10 years period of RPKH, annual forest resources evaluation, and quarterly reports by KRPH supervised by SPH. Because the social data was not being an input, there was no updating procedure for social data although social dynamics changing surround the forest area occurred rapidly.

In the context of forest resources planning, updating data process was used to support planning activities. Meanwhile, in the forest resources management context, updating data process was used to support the management decision-making process by providing the needs of latest information.

Turban et al. (2007) stated that the ability of information system to improve the quality of decision-making process requires integration of data from the various source. A missing procedure found in the SISDH of Perum Perhutani was the data integration or sharing data procedures among various divisions in the organization. Integrating heterogeneous data sources is a fundamental problem in databases, especially with a complex database such forest management. Driven by the need to integrate all available data from distributed sources, many types of research were focused on data integration process. Thus, data integration is the combination of heterogeneous data residing at different resources, and providing the user an integrated and reconciled view of data in order to extract explicit information at different level of the decision-making process (Cali et al. 2004). Moreover, data integration also gives users the opportunity to make an integrated analysis of prior information. Integration data more than a simple overlay or integration. It is rather towards exchange between individual objects in various information systems (Siham et al. 2016).

The forest resource information system was exclusively used for physical data of forest resources. Thus, the forest resources planning and management focus only on the physical potential of forest resources. The forest resources information system in Perum Perhutani is not a system that could provide a holistic perspective in presenting alternative options to solve a problem or achieve the

3 User goal of the organization.

The user of information system in the forest resources planning and management context is shown in Table 2 . Each user has different characteristics due to their difference authority in each work unit. Table 2 shows the lowest level of work unit authorize to decide planning decision is at regional division unit as a representative of board of directors. Refers to the sources, the implication of current organization structure put KPH as executor of plans which have been decided by the higher level of the work unit. KPH which directly in touch with forest resources has only authorized to propose, instead of deciding the management plan for forest resources. The implication of this organizational structure placed a unit at the site level such KPH to become only an information provider instead of information user because they did not have authority to make a decision. These conditions would lead to inefficiency of the decision-making process because there more bureaucracy processes to be through.

4 Technology

Information technology is defined as a set of shared information technology resources which is a foundation for both communication across the organization and the use of present or future business application (Chanopas et al. 2006; Hartono et al. 2010). Information technology capability entails the use of technology to facilitate the organizational process. An organization's information technology capability is crucial for its competitive advantage (Lin 2007; Haron \& Hawedi 2015).

Technology in the SISDH at Perum Perhutani is called SAS. SAS has been operated since 1994. It was used to computerize the counting of production etat and has not been updated until now. SAS has a shortcoming, it is only can be operated by trained operator. In addition, this application has not been integrated with the lowest unit to the board of directors level, so that it causes inefficiencies in the access of 
Table 2 Type of planning, drafter, evaluator, and certifier of planning documents in Perum Perhutani

\begin{tabular}{|c|c|c|c|c|}
\hline Working unit & Type of planning & Drafter & Evaluator & Certifier \\
\hline \multirow[t]{6}{*}{$\begin{array}{l}\text { Board of } \\
\text { directors }\end{array}$} & RUP & Board of Directors & BOD \& Supervisory Board & $\begin{array}{l}\text { Ministry of Environment } \\
\text { and Forestry }\end{array}$ \\
\hline & RJP & Board of Directors & BOD \& Supervisory Board & $\begin{array}{l}\text { Minstry of State-owned } \\
\text { Enterprises }\end{array}$ \\
\hline & RKL & Board of Directors & BOD \& Supervisory Board & $\begin{array}{l}\text { Ministry of Environment } \\
\text { and Forestry }\end{array}$ \\
\hline & RKT & Board of Directors & BOD \& Supervisory Board & $\begin{array}{l}\text { Ministry of Environment } \\
\text { and Forestry }\end{array}$ \\
\hline & RKAP & Board of Directors & BOD \& Supervisory Board & $\begin{array}{l}\text { Minstry of State-owned } \\
\text { Enterprises }\end{array}$ \\
\hline & RO & $\begin{array}{l}\text { President Director/Head of } \\
\text { Agency/KSPI }\end{array}$ & RKAP Team & Director of Finance \\
\hline \multirow{6}{*}{$\begin{array}{l}\text { Regional } \\
\text { division }\end{array}$} & RUP & Head of Regional Division & Head of PP & President Director \\
\hline & RJP & Head of Regional Division & Head of PP & President Director \\
\hline & RKL & Head of Regional Division & $\begin{array}{l}\text { Head of Forestry } \\
\text { Department of Province }\end{array}$ & Governor \\
\hline & RKT & Head of Regional Division & $\begin{array}{l}\text { Head of Forestry } \\
\text { Department of Province }\end{array}$ & Director of Finance \\
\hline & RKAP & Head of Regional Division & Head of PP & Director of Finance \\
\hline & RO & Bureau Chiefs & Head of PP & Head of Regional Division \\
\hline \multirow[t]{6}{*}{$\mathrm{KPH}$} & RPHL/RPKH & Head of Planning Section & Head of Planning Bureau & Head of Regional Division \\
\hline & RJP & Head of KPH & Head of Planning Bureau & Head of Regional Division \\
\hline & RTT & Head of KPH & Head of Planning Section & Head of Regional Division \\
\hline & RKT & Head of KPH & Head of Planning Section & Head of Regional Division \\
\hline & RKAP & Head of KPH & Head of Planning Bureau & Head of Regional Division \\
\hline & RO & Section Chief of Forest & Vice Chief of KPH & Head of KPH \\
\hline
\end{tabular}

information. The software for spatial data is ArcView. Output data from both software must be connected manually. On the other hand, the connection constrained by bureaucracy because the authorized division for spatial data was only put on the regional division. SPH as the planner on the site level does not have authority and resources to manage spatial data so that, it could be found the case of forest resources data and spatial data did not match each other.

Haron and Hawedi (2015) stated that information technology capability contributes towards better decision making where companies management can decide on their investment for their companies in the future. The lack of information technology capability in Perum Perhutani has shown the lack of decision-making process in term of use of information system organization. Perum Perhutani needs to improve their information technology. Improvements in information technology not only consider about the technology itself but also how the user's acceptance and capability to operate the information technology. The research findings suggest various factors that can influence user's decision when adopting technology. These factors include socio-cognitive factors such as perceptions and expectations of the technology and self-efficacy, relevance to the task, and social and institutional factors (Lin 2006).

From the indicators of information system proposed by DeLone and McLean (2013) and Athanasiadis and Areopoulou (2013), information systems currently used by Perum Perhutani still, has weakness in system quality and service quality. While the quality of forest resources information rated enough to be used in forest resources management. Turban et al. (2007) suggested that an organization's information technology can integrate all needed information by the organization. Information technology is not only related to the software or hardware of information system platform, but more than that including system development, risk management and data security, and data management as a part of technology information infrastructure as shown in Figure 3. Observation to the technology information in the SISDH in Perum Perhutani has not been built as a complete technology information infrastructure that supports the existence of information systems.

Todays, Perum Perhutani has been running towards improved management of forest resources. One of the steps is the improvement of information systems. Developed improvement of information system tries to integrate the social information and biophysical information into forest resources databases. It has been carried out in the form of site typology. This is the initial step to build an ideal information system towards better forest resources management.

Technical variable of system information such system information infrastructure has an important rule to the success information system. On the other side, there is also a correlation between information system and organization which implicates one to another. Agourram (2009) conducted research about success information system in Germany. The result showed that participants strongly believe that a successful information system changes the culture of the organization. Information system success is a concept that concerns socio-technical system; it is indeed 


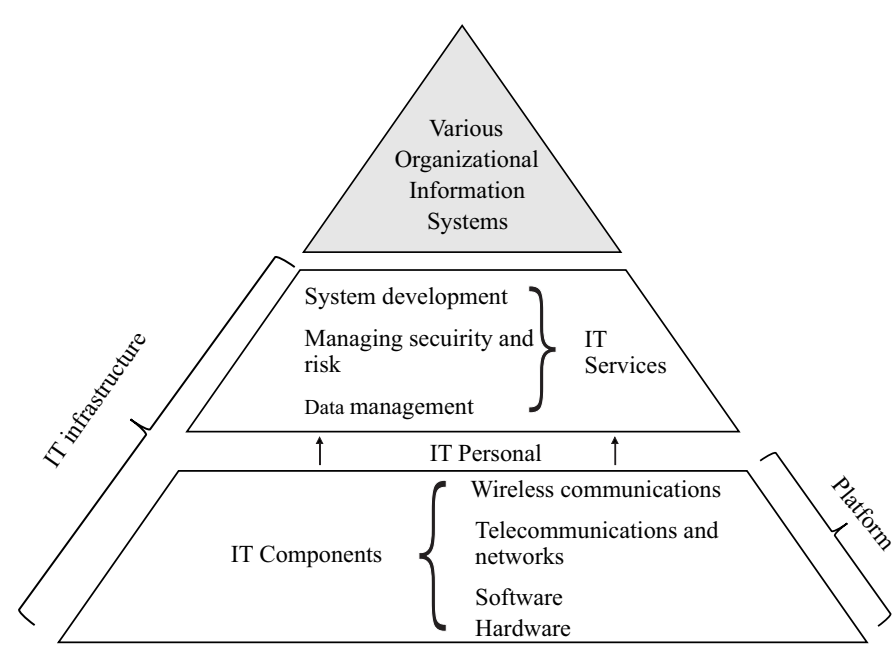

Figure 3 Components of information system (Turban et al. 2007).

affected by culture. The meaning of information and effectiveness of information systems could vary substantially in different cultures. Information systems have built-in values that reflect the value priority of the cultures in which they are developed. So does the existing information in Perum Perhutani. It works correlatively with the organization structure which determines the organization culture. Effect of SISDH to the decision of forest resources management in Perum Perhutani.

Information system works by collecting, processing, analyzing, and disseminating available information to the various levels of management Information system product does not automate the decision-making process. The final decision remains in the hands of manager by considering the available information, shared values, and preferences that could be accumulated from experiences and knowledge background (Varma et al. 2000; Schuck et al. 2007). Figure 3 illustrates information system framework related to the decision-making process which is influenced by 3 variables that have been mentioned before. A decision occurs when an alternative action is selected and implemented through its internalization in policy, plans or an institutional arrangement, and typically operationalized as some form of regulation or incentive. Management decision should account for the values and preferences stakeholders (Martinez-Harms et al. 2015).

The decision-making process was observed in the forest resources planning and management context. In the forest resources planning context, we observed the drafting process of forest management plans. While in the forest resources management context, we observed the forest resources management decision. Both forest planning and management context were observed in the level of KPH, $\mathrm{SPH} /$ regional division, and board of directors.

Forest resources planning in Perum Perhutani consists of the RPKH and its detail plan such as RTT. Forest resources planning only focus on forest resources physical planning such as nursery, planting, maintenance, and harvesting activities. Social and environmental management were not integrated into the forest resources management plan. In terms of decision-making, KPH as unit management at the site level has been positioned as executor of planning made by the upper-level work unit.

Organizational structure can be defined as a mechanism which links and coordinates individual within the framework of their roles, authority, and power. The organizational structure represents a useful tool that directs individual's behavior through shared values, norms, and goals (O'Neil et al. 2001; Liao et al. 2011; Kanten et al. 2015). Frederickson (1986) stated that the strategic decision-making process is affected by its organizational structure. The recent organizational structure of Perum Perhutani is centralized. Centralized refers to the degree of the right to make a concentrated decision and evaluation activities. The high level of centralization is the most obvious way to coordinate organization decision making, but it requires significant cognitive demands on those managers who retain authority. The individuals in this type of organizational structure have no cognitive capacity or information that is needed to understand all the decisions that are faced by the complex organization. Therefore, it is not surprising that negative relationship has been reported between organization's size and its degree of centralization. Next implication will be in line with (Baligh 2006) that organization structure would affect organization's performance and together with its environmental will determine organization's outcome.

The implication of organization structure is not only in the forest planning activities but also in the forest management. For daily decision making, the head of KPH is only authorized to propose management activities or settlements for any problems on the site to regional division level. Regional division has the authorization to approve or refuse the proposal as a representative of board of directors. This leads to inefficiencies in the decision-making process because the bureaucratic process is time and cost consuming. $\mathrm{KPH}$ as the lowest level of unit management has more holistic information about potential and problem on the site. But in this condition, forest management unit only has ruled as an information provider, not information user because they have no authority to use the information.

Figure 4 shows information system framework for decision-making. The decision-making process is influenced by information, value, and preferences of the decision maker. This research attempts to reveal the dominant variable used by the decision maker in Perum Perhutani related to management forest resources. Value is a concept which led to choice and action (Brown 1984). Harris (2015) stated that preferences is a reflection of the personal value of decision makers. Preferences of decision maker affected by goals, cognitive ability, and experiences (Warren et al. 2010). In sustainable development concept, there are 3 values of development. They are a technocratic paradigm, precautionary principle, and social equity. Technocratic paradigm explained by (Drengson 2011) as an anthropocentric development concept. Nature becomes an object of exploitation due to its economic value and to full fill humans need. Ecosystem services are defined as the benefits 
that ecosystem provide to human. It is based on flow since it refers to services. It depends on context time and space, and it mimics weak sustainability. Nonetheless, it is sufficiently broad that it includes both short-run and long-run benefit as well as use values and non-use value (Zagonari 2016).

Beder (2006) discussed precautionary principle and social equity concept. Precautionary principle concept comes from understanding that human activities to develop potentially cause harm to the human nor the environment. To meet the demands of growing population, human activities will continue to cause significant changes to land cover, climate, biogeochemical cycles, biodiversity, and ecosystem services (Foley et al. 2011). Thus, it necessary precaution to anticipate the harm. Meanwhile, social equity or social justice mean that every individual has access and equal opportunities to leverage the resources and there is no individual or group of individuals who bear more development externalities than others.

From the interviews in each unit level of management that were observed, it concludes that decision-making management of forest resources in line with the technocratic paradigm value. This was indicated by the key informants' statement that forest resources management planning focused on the exploitation of forest resources to gain profit. More technically, the decision makers used preferences as a dominant variable in the decision-making process. Forest resources management runs according to the experiences or action that have been carried out by predecessors. The centralized structure that previously described limits the creativity of individuals to act out of habit. Thus, the rational choice is to follow the pattern of decision-making has ever done by the predecessor. It is in line with the research result of Negulescu and Doval (2014) that most of the decision maker make their decisions on the basis of their experiences. The decision makers are not usually using scientific methods when making a decision but based on their experience and historical events. The decision makers usually avoid the risk when making a decision. The large experimental literature demonstrates that self-regarding preferences are very strong and in the context such as a workplace, their influence on behavior is powerful (Frohlich \& Oppenheimer 2006; BenNer 2013).

Forest resources information system to support sustainable forest management Sustainable forest management had become an ideal concept to manage forests in many years. FAO (1994) defined sustainable forest as the management and conservation of the natural resources base and the orientation of technological and institutional change in such a manner as to ensure the attainment and continued satisfaction of human needs for present and future generations. As it was concept developed, various instruments to support the realization of sustainable forest managements were prepared. Criteria and indicators of sustainable forest management have been developed through the work of many stakeholders including governments, nongovernments organization, research organizations, and private companies (MacDicken et al. 2015).

Forest management certification provides independent verification of adherence to a defined set of management standards that promote and measure sustainable forest management (CEPI 2006). In Indonesia, Forest Stewardship Council (FSC) and Lembaga Ekolabel Indonesia (LEI) are the commonly used certification standards for sustainable forest management. Both institutions have suitable criteria and indicators to apply in Indonesia.

Forest resources information systems is an instrument to support sustainable forest management. To fulfill the needs, Franklin (2001) suggested to look at the criteria and indicators lists and begin to construct a list of the data and information that would be required in order to understand if current or future practices are sustainable in managing a forest. Criteria and indicators of FSC and LEI for were classified into 3 class. They were ecology aspect, socioculture aspect, and production aspect. It was used to observe the forest resources information system of Perum Perhutani.

Current forest resources information system in Perhutani shown weakness in 4 observed variables of the information system. In variable of data and information, observation unit became an issue. For social information, subplot should be the observation unit to consider the rapid change of social dynamics. In variable of procedure, information integration and information service were the issues. Perum Perhutani needs to prepare a mechanism to integrate various information from various sources that can be easily accessed by the user. Social, environmental, and forest resource information are not a single variable to decide the planning and management of forests. Besides that, Perum Perhutani should integrate various information systems within the organization including management information system, financial information system, and marketing information system. Information services should manage which information can be accessed by what kind of user. In variable of technology, Perum Perhutani should have technology which supports a real-time access to the information and faster process to update the information. Perum Perhutani needs an online system to facilitate an easy access to the information. Updating data/information process can use technology such as global positioning systems (GPS), satellite images, drone or handphone to produce information from the sites. In variable of a user, KPH as manager in the site should not be only the information provider but also should be the information user. It's important to make sure the decision-making process in the site run efficiently. Spatial information which managed by regional division should be shared to $\mathrm{KPH} / \mathrm{SPH}$ level to support planning and management process in the sites.

Todays, Perum Perhutani try to change their management of the forest. One of the transformation is support KPH as production unit to become an independent unit. The main idea of it is KPH as unit management in the sites level can contribute to upgrading the land value by upgrade the public benefit of forests. This changing needs requirements such as:

1 Management plan based on the typology of KPH.

2 Delegate authorization of forest management decision to the KPH.

3 Preparation of human resources in KPS based on management pla.

4 Manage the transformation.

The current forest resources information system in Perum Perhutani can not fulfill the needs of this transformation 
cause of the weakness that explained before. Besides that, adoption of international accounting standard (IAS) 41 for Agriculture issue in 2017 will affect forestry companies. IAS 41 rules accounting for biological assets including plants and animals especially the inventaritation. Its implicate to the needs of a forest resources information system that can provide an accurate and actual data and information periodically. Thus, Perum Perhutani should fix their forest resources information system.

\section{Conclusion}

The current information system of Perum Perhutani has not supported sustainable forest management yet. It has weakened in 4 observed variables of information systems. They are data and information, procedure, technology, and user. The state of current forest resources information system affects the organization structures. In the decision-making process, in value context, Perum Perhutani adopts the technocratic paradigm but in the process, it is technically dominated by the preferences of the decision-maker. The organization structure of Perum Perhutani which is centralized affects the use of information and decisionmaking at the site level. The KPH as a manager of forest resources at the site level only becomes a provider of information and have no authority to use the information for deciding the management of forest resources.

\section{Recommendation}

Perum Perhutani needs to fix their forest resource information system in order to support sustainable forest management. Variables to fix are data and information, procedure, technology, and user. Besides that, Perum Perhutani needs to consider the changing of organization structure which could give forest management unit at the site level authorization for decision-making.

\section{Acknowledgement}

Authors would like to express sincere gratitude to Perum Perhutani for providing data and permit. Also for key informants from Perum Perhutani who has made time to be interviewed in order to complete this research.

\section{References}

Agourram H. 2009. Defining information system success in Germany. International Journal of Information Management 29:129-137. https://doi.org/10.1016/ j.ijinfomgt.2008.05.007.

Arias JM, Solana JM. 2013. Information system supported organizational learning as a competitive advantage. Journal of Industrial Engineering and Management 6(3):702-708. https://doi.org/10.3926/jiem.555.

Athanasiadis A, Areopoulou Z. 2013. A web information systems application of forest legislation: the case of Greek Forest Principles. Procedia Technology 8:292-299. https://doi.org/10.1016/j.protcy.2013.11. 039 .

Atrishchenko OA. 2013. Forest stand and growth forecast models. Proceeding of BSTU 2013(1):3-5.

Baligh HH. 2006. Organization Structures: Theory and Design, Analysis and Prescription. New York: Springer.

Beder S. 2006. Environmental Principles and Policies: An Interdisciplinary Introduction. New South Wales: University of New South Wales Press Ltd.

Ben-Ner A. 2013. Preferences and organization structure: towards behavioral economics micro-foundation of organizational analysis. The Journal of Socio-Economics 46:87-96. https://doi.org/10.1016/j.socec.2013.08.003.

Buckingham RA, Hirschheim RA, Land FF, Tully CJ. 1987. Information Systems Education : Recommendation and Implementation. New York: Press Syndicate of the University of Cambridge.

Bungin B. 2003. Analisis Data Penelitian Kualitatif: Pengalaman Filosofis dan Metodologis ke Arah Penguasaan Model Aplikasi. Jakarta: Raja Grafindo Persada.

Brown CT. 1984. The concept of value in resource allocation. Land Economics. 60:231-246. https://doi.org/10. 2307/ 3146184 .

Cali A, Calvanese D, De Giacomo G, Lenzerini M. 2004. Data integration under integity constraints. Information Systems 29:147-163. https://doi.org/10.1016/S03064379(03)00050-4.

[CEPI] Confederation of European Paper Industries. 2006. A Comparison of the Forest Stewardship Council and the Programme for Endorsement of Forest Certification. Brussel: CEPI.

Chanopas A, Krairit D, Khang DB. 2006. Managing information technology infrastructure: A new flexibility framework. Management Research News 29(10):632-651. https://doi.org/10.1108/014091706107 12335 .

Cheung L, Austin K, Utami A, Bangoura J, Stolle F. 2014. Building National Forest Land Use Information Systems: Lesson from Cameroon, Indonesia and Peru. Available on: http://www.wri.org/sites/default/files/land-useinfomation_systems_working_paper.pdf. [October 2015].

Creswell JW. 2012. Research Design: Pendekatan Kualitatif dan Kuantitatif dan Mixed. Fawaid A, penerjemah. Yogyakarta: Pustaka Pelajar.

DeLone WH, McLean ER. 2003. The DeLone and McLean model of information systems success: a ten year update. Journal of Management Information Systems 19(4):9-30.

Denzin NK, Lincoln YS. 2009. Handbook of Qualitative Research. Yogyakarta: Pustaka Pelajar. 
[FAO] Food and Agriculture Organization. 1994. Reading in sustainable forest management. Available on: http://www.fao.org/docrep/015/T0843e/T0843e00.pdf [August 10, 2016].

Fakultas Kehutanan Universitas Gajah Mada. 2014. Laporan Akhir Ekstensifikasi Model Kelola Informasi SDH Hutan di Tingkat KPH. Yogyakarta: Universitas Gajah Mada.

Franklin SE. 2001. Remote Sensing for Sustainable Forest Management. Washington D.C.: Lewis Publisher.

Frederickson JW. 1986. The strategic decision process and organizational structure. The Academy of Management Review 11:280-297.

Foley JA, Ramankutty N, Brauman KA, Cassidy ES, Gerber JS, Johnston M, Mueller ND, O'connel C, Ray DK, West PC. 2011. Solution for a cultivated planet. Nature 478:337-342. https://doi.org/10.1038/nature10452.

Frohlich N, Oppenheimer J. 2006. Skating on thin ice: cracks in the public choice foundation. Journal of Theoretical Politics 18(3):235-266. https://doi.org/10.1177/095162 9806064346.

Harris R. 2015. Introduction to decision making. Available on: http://www.virtualsalt.com/crebook56.htm. [Juni 2016].

Haron H, Hawedi HS. 2015. Information technology capability as predictor of organizational intelligence in Libyan oil and gas company. ARPN Journal of Engineering and Applied Sciences 10(23):220-227.

Hartono E, Li X, Na K, Simpson JT. 2010. The role of the quality of shared information in interorganizational system use. International Journal of Information Management 30:399-407. https://doi.org/10.1016/ j.ijinfomgt. 2010.02.007.

Kanten P, Kanten S, Gurlek M. 2015. The effects of organizational structures and learning organization on job embeddedness and individual adaptive performance. Procedia Economics and Finance 23(2015):1358-1366. https://doi.org/10.1016/S2212-5671(15)00523-7.

Liao C, Chuang SH, To PL. 2011. How knowledge management mediates the relationship between environment and organizational structure. Journal of Business Research 64(7):728-736. https://doi.org/ 10.1016/j.jbusres.2010.08.001.

Lin A. 2006. The acceptance and use of a business-to-business information system. International Journal of Information Management 26:386-400. https://doi.org/10.1016/ j.ijinfomgt.2006.04.002.

Lin BW. 2007. Information technology capability and value creation: evidence from US banking industry. Technology in Society 29(1):93-106. https://doi.org/10.1016/j. techsoc.2006.10.003.
MacDicken KG, Sola P, Hall JE, Sabogal C, Tadoum M, de Wasseige C. 2015. Global progress toward sustainable forest management. Forest Ecology and Management 352(2015):47-56. https://doi.doi.org/10.1016/j.foreco. 2015.02.005.

Marchand DA, Kettinger WJ. 2011. Information orientation (IO): how effective information use drives bussiness performance. Sitemas 1:75-84.

Martinez-Harms MJ, Bryan BA, Balvanera P, Law EA, Rhodes JR, Possingham HP, Wilson KA. 2015. Review: maing decision for managing ecosystem services. Biological Conservation 184:229-238. https://doi.org/ 10.1016/j.biocon.2015.01.024.

O'Neill JW, Beauvais LL, Scholl RW. 2001. The use of organizational culture and structure to guide strategic behavior: an information processing perspective. The Journal of Behavioral and Applied Management 2(2):131-149.

Pearlson KE, Saunders CS. 2010. Managing and Using Information Systems: A Strategic Approach. Danvers: John Wiley \& Sons, Inc.

Perum Perhutani. 2000. Standar Prosedur Operasi Sistem Informasi Sumberdaya Hutan dan Sistem Informasi Geografis dengan Pengolahan Data Elektronik. Jakarta: Direksi Perum Perhutani.

Perum Perhutani. 2010. Redesain Pengelolaan Sumber Daya Hutan Perum Perhutani Unit II Jawa Timur. Jakarta: Direktorat Perencanaan dan Pengelolaan Sumber Daya Hutan Perum Perhutani.

Perum Perhutani. 2015. Profil Perusahaan 2015. https://www.dropbox.com/s/bjvo5ut094rbeki/2016Company\%20Profil.pdf?dl=0 [August 2016].

Platisa G, Balaban N. 2009. Methodological aproach to evaluation of information system functionality performances and importance of successfulness factor analysis. The International Scientific Journal of Management Information System 4(2):11-17.

Prasetyo LB. 2013. Land use, climate chane and biodiversity modelling: persepectives and application 2011, 512 pages. Jurnal Manajemen Hutan Tropika 19(3):211-213. https://doi.org/10.7226/jtfm.19.3.211

Rondeaux J. 1991. Management Information System: Emerging Tools for Integrated Forest Planning. Paper for IUFRO Symposium on Integral Forest Management Information System. Available on http://www.gembloux. ulg.ac.be/gestion-des-ressources-forestieres-et-desmilieux-naturels/wp-content/uploads/Cahiers forestiers/CaFor10.pdf- [October 2015].

Scuck A, Green T, Andrienko G, Andrienko N, Fedorec A, Requardt A, Richards T, Mills R, Mikkola E, Päivinen R, Köhl M, San-Miguel-Ayanz J. 2007. Towards a 
European Forest Information Systems. Netherland: European Forest Institute.

Siham L, Hammani A, Bouignane A. 2016. Data integration as the key to building a decision support system for groundwater management: case of Saiss Aquifers, Morocco. Groundwater for Sustainable Development 2-3:7-15. https://doi.org/10.1016/j.gsd.2016.04.003.

Turban E, Rainer KR, Potter RE. 2007. Introduction to Information System. New York: Jhon Wiley and Sons, Inc.
Varma VK, Ferguson L, Wild J. 2000. Decision support system for the sustainable forest management. Forest Ecology and Management 128:49-55. https://doi.org/ 10.1016/S0378-1127(99)00271-6.

Walsham G. 2009. Interpreting Information System in Organizations. Blackwell: Chichester.

Zagonari F. 2016. Using ecosystem services in decisionmaking to support sustainable development: critiques, model development, a case study and perspective. Science of Total Environment 548-549:25-32. https://doi.org/10.1016/j.scitotenv.2016.01.021. 